\title{
Seasonal Variation in Essential Oil Content, Chemical Composition and Antioxidant Activity of Teucrium polium L. Growing in Mascara (North West of Algeria)
}

\author{
Yamina Maizi ${ }^{*}$, Boumediene Meddah¹, Aicha Tir Touil Meddah¹, Jose Antonio Gabaldon Hernandez ${ }^{2}$ \\ ${ }^{1}$ Laboratory of Bioconversion, Microbiology Engineering and Health Safety (LBGMSS), Faculty of Nature and Life Sciences, University \\ Mustapha Stambouli of Mascara, Mascara, Algeria \\ ${ }^{2}$ Laboratory of Recognition and Molecular Encapsulation (REM), Faculty of Health Sciences, Catholic University San Antonio of Murcia, \\ Murcia, Spain
}

Corresponding Author: Yamina Maizi, PhD, Laboratory of Bioconversion, Microbiology Engineering and Health Safety (LBGMSS), Faculty of Nature and Life Sciences, University Mustapha Stambouli of Mascara, Mascara, Algeria. Tel: +213-791259924, Email: yamina.maizi@univ-mascara.dz

Received June 15, 2019; Accepted September 19, 2019; Online Published December 5, 2019

\begin{abstract}
Introduction: Phytochemicals are one wide class of nutraceuticals found in plants which act as antioxidants. In this research, the essential oil (EO) of Teucrium polium L., Lamiaceae, collected from Mascara province, situated in the Algerian northwestern, where their chemical composition varies according to geographical origin, season variation, and climatic conditions were studied.

Materials and Methods: The extraction of EO was performed by hydrodistillation. Then, the chemical compounds were identified by gaz chromatography coupled to a mass spectrometer (GC-MS). In parallel, the antioxidant activity was evaluated using the DPPH test.

Results: The yield of the EO of T. polium L. varied during different seasons with the highest in winter season, at vegetative stage (S1), while the same EO (S1) was significantly more efficient as an antioxidant than the EO harvasted at the flowering stage (S2) with IC50 values $3.90 \pm 0.05$, $16.14 \pm 0.15 \mathrm{mg} / \mathrm{mL}$, respectively $(P<0.001)$. These extracts are predominantly constituted by limonene $(29.87 \%-26.39 \%)$, spathulenol $(17.24 \%-$ $13.29 \%)$, camphor $(0.0 \%-8.20 \%)$, pinocarvone $(7.76 \%-5.60 \%)$, tau-cadinol $(5.41 \%-3.67 \%)$, pinene oxide $(0.0 \%-4.78 \%)$, $\alpha$-terpineol $(0.0 \%$ $4.6 \%)$, 1-adamantanemethylamine $(0.0 \%-9.80 \%)$ and $\beta$ - myrcene $(0.0 \%-4.02 \%)$.

Conclusions: The results show that both EOs can be considered as potential sources of natural antioxidants. However, the vegetative stage was the best stage for harvesting the EO of T. polium L. which can be used as an alternative source of synthetic compounds.

Keywords: Teucrium polium L., Mascara, Essential Oil, Vegetative Stage, Flowering Stage, Antioxidant

Citation: Maizi Y, Meddah B, Tir Touil Meddah A, Gabaldon Hernandez JA. Seasonal variation in essential oil content, chemical composition and antioxidant activity of Teucrium polium L. growing in Mascara (North West of Algeria). J Appl Biotechnol Rep. 2019;6(4):151-157. doi:10.29252/ JABR.06.04.04.
\end{abstract}

\section{Introduction}

Oxidative stress is involved in many human diseases ranging from inflammation to cancer. ${ }^{1}$ Thus, the development of new therapeutic agents proves to be indispensable in the fight against this phenomenon.

Many researchers have indicated that essential oils (EOs) are considered as really active antioxidants. ${ }^{2,3}$ Recently, many antioxidant metabolites have been isolated from Mediterranean plants like Origanum vulgare L., Salvia officinalis L. and Thymus vulgaris L., of which several belong to the Lamiaceae family. ${ }^{4}$ The Teucrium genus (from the Lamiaceae family) includes 340 species distributed in the arid and rocky areas of the Mediterranean basin, ${ }^{5}$ of which 20 of them were reported in Algeria. ${ }^{6}$

Teucrium polium L. (germander) which is locally called Jâada (or Gattaba, khayatat lajrah) and is widely found in Mascara (North West of Algeria) has a small cluster of pink to white flowers. This plant has been used for over 2000 years in traditional medicine due to its hypoglycemic, antispasmodic, diuretic, ${ }^{7}$ anti-inflammatory, anti-rheumatoid, ${ }^{8}$ hypolipidemic, ${ }^{9}$ antioxidant, ${ }^{10,11}$ analgesic, antipyretic, wound healing, anti-microbial ${ }^{12}$ and cardioprotective properties. ${ }^{13}$

Thus, the biological activities of the genus Teucrium EOs depend on their chemical compounds which can be affected by geographic origin, environmental conditions (precipitation, temperature, etc) and stage of development. ${ }^{14,15}$ It has been seen that studies on the effect of abiotic and biotic factors on oil chemical compositions and biological activities of some medicinal and aromatic plants are available. ${ }^{16-19}$

However, no reports have been found concerning the EO of T. polium L. growing in Mascara. Therefore, the aim of the present study is to evaluate the variation of the chemical composition, oil yield and antioxidant activity of T. polium EO collected in North West of Algeria (Mascara province),

Copyright $\odot 2019$ The Author(s). This is an open-access article distributed under the terms of the Creative Commons Attribution License (http:// creativecommons.org/licenses/by/4.0), which permits unrestricted use, distribution, and reproduction in any medium, provided the original work is properly cited. 
at different phenological stages (vegetative and flowering). This was done to select the best stage of harvest which would obtain the best quality and quantity of natural substances in EOs.

\section{Material and Methods \\ Plant Material Collection}

Teucrium polium L. samples were collected at two phenological stages of 2015: vegetative in January-February and the flowering in May-June, from El Mamounia (Altitude: $658 \mathrm{~m}$; Latitude: $35^{\circ} 25^{\prime} 29^{\prime \prime} \mathrm{N}$; Longitude: $0^{\circ} 8^{\prime} 26^{\prime \prime} \mathrm{E}$ ), situated in the North West of Algeria (Mascara province). About 800 g-100 $0 \mathrm{~g}$ of aerial parts of T. polium L. were isolated in laboratory. The authentication of plant species was carried out using the African flowering plants database and also by the intervention of different botanists of Biology department of the University of Mascara.

\section{Essential Oil Extraction}

Samples of $60 \mathrm{~g}$ of the aerial part of the plant (stem and leaves) were extracted by hydrodistillation using a Clevengertype apparatus according to the method recommended in the European Pharmacopoeia. ${ }^{20}$ Then, the obtained EO was dehydrated with anhydrous sodium sulphate and kept at $+4^{\circ} \mathrm{C}$ in the dark until used. EO extractions were done in three replications and the extraction yield was expressed as the weight of EO volume on the weight of plant used (W/W).

\section{Physicochemical Characteristics of Essential Oil}

The physicochemical properties of the extracted EO were the organoleptic characteristics (appearance, color, smell), the chemical indexes such as $\mathrm{pH}$ value, acid and ester values and the physical indices for example refractive index and relative density. ${ }^{21}$

\section{GC-MS Analyses}

The identification of different chemical compounds of EOs was carried by a gas chromatography-mass spectrometry (GC-MS) type Shimadzu QP2010 using a SUPELCO column $(30 \mathrm{~m} \times 0.25 \mathrm{~mm}$ fused silica capillary column) and 0.25 $\mu \mathrm{m}$ film thickness, the oven temperature was held at $60^{\circ} \mathrm{C}$ then programmed to $250^{\circ} \mathrm{C}$ at rate of $2^{\circ} \mathrm{C} \mathrm{min}{ }^{-1}$ during 110 minutes under the following conditions: helium was used as carrier gas at a flow rate of $1.13 \mathrm{~mL} / \mathrm{min}$; injector and detector temperatures: $250^{\circ} \mathrm{C}$; injected volume: $1.0 \mu \mathrm{L}$ by split less method, ionization energy $70 \mathrm{eV}$.

The oil chemical compounds were identified by comparison of their mass spectra, retention times and retention indices with those cited in the literature and given by the spectral library banks (NIST).

\section{Antioxidant Activity}

\section{DPPH Assay}

The antioxidant activity of the EOs (S1, S2) and the standard antioxidant ascorbic acid were determined on the basis of the radical scavenging effect of the stable 2, 2-diphenyl-1picrylhydrazyl (DPPH) free radical activity according to the method described by Brand-William et al. ${ }^{22}$ Fifty microliter of different concentrations of each sample were added to $1950 \mathrm{~mL}$ of methanol solution of DPPH $(0.025 \mathrm{~g} / \mathrm{L})$. After incubation at room temperature for 30 minutes, the absorbance of these solutions was read at $517 \mathrm{~nm}$ against a control (containing only the DPPH solution) by UV-Visible Spectrophotometer (SHIMADZU, UVmini-1240) and the percentage inhibition (I\%) was calculated using the following formula:

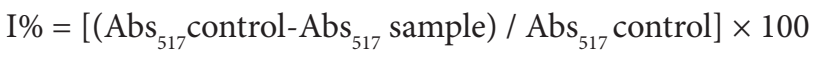

The concentration of sample necessary to scavenge $50 \%$ of the $\mathrm{DPPH}$ radical $\left(\mathrm{IC}_{50}\right)$ was calculated from the regression equations derived by the least-square method and prepared from the different concentrations of EOs. ${ }^{23}$ A higher DPPH radical-scavenging activity is associated with a lower $\mathrm{IC}_{50}$ values. All tests were carried out in triplicate.

The antioxidant activity was also expressed as ascorbic acid equivalent antioxidant capacity (AEAC) according to the equation:

$\mathrm{AEAC}=\left[\mathrm{IC}_{50}\right.$ (ascorbic acid $) / \mathrm{IC}_{50}($ sample $\left.)\right] \cdot 10^{5} \cdot{ }^{24,25}$

Data Analysis

The results are presented as mean \pm SEM. Statistical analysis was performed by one-way analysis of variance (ANOVA) and $P \leq 0.05$ were considered as significant.

\section{Results}

Yield and Physicochemical Analysis of Essential Oil

Essential Oils extracted from aerial parts including stems, leaves of $T$. polium harvested during the vegetative (S1) and the flowering (S2) stages of growth showed a variable physicochemical characteristic (Table 1) accompanied by an oily liquid aspect, a light yellowish color with a strong odor. The yields of EO extracted from two stages (S1, S2) are variable (Table 1). This difference has been explained mainly by the influence of climatic conditions.

The meteorological data during 2006 to 2015 showed that the vegetative stage coincided with the winter period while the flowering stage coincided with the summer period (Figure 1). The values are obtained from the National Office of Meteorology.

In addition, the average rainfall (2006 to 2015) was 408.1 $\mathrm{mm}$ fairly well distributed; the maximum rainfall received in autumn and winter were $58.2 \mathrm{~mm}$ and $565 \mathrm{~mm}$ respectively, $171.7 \mathrm{~mm}$ received in spring and $62.7 \mathrm{~mm}$ in summer.

Table 1. Physicochemical Analysis and yield of Essential oil of Teucrium polium L.

\begin{tabular}{lcc}
\hline & S1 & S2 \\
\hline $\mathrm{R} \%$ & $0.82 \pm 0.027$ & $0.56 \pm 0.032$ \\
Chemical indexes & & \\
$\mathrm{pH}$ & 7.5 & 7.9 \\
Acid value & 1.56 & 4.83 \\
Ester value & 17.98 & 19.43 \\
Physical indexes & & \\
The relative density at $20^{\circ} \mathrm{C}$ & 0.28 & 0.37 \\
Refractive index & 1.427 & 1.427 \\
\hline
\end{tabular}




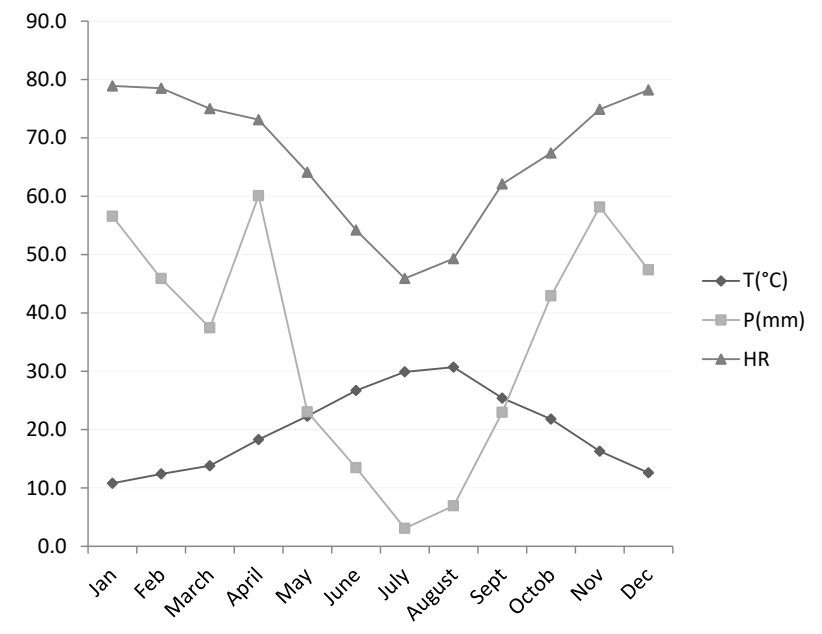

Figure 1. Climatic Conditions in Mascara During Period 2006-2015. T: Average of temperatures in ${ }^{\circ} \mathrm{C}, \mathrm{P}$ : Average of precipitations in $\mathrm{mm}, \mathrm{RH}$ : Average of relative humidity in $\%$.

The maximum temperature recorded in August was $30.7^{\circ} \mathrm{C}$. The coldest month was January with $10.8^{\circ} \mathrm{C}$ while August was the hottest. The average relative humidity varied from $78.9 \%$ in January to $45.9 \%$ in July. It was quite high in winter and spring with values greater than $60 \%$. According to the KöppenGeiger classification, Mascara has a warm Mediterranean climate with dry summer (Csa) (http://koeppen-geiger.vuwien.ac.at/).

\section{Chemical Composition}

Qualitative and quantitative analysis of the EOs from the vegetative period (winter leaves) and the flowering (summer leaves) of T. polium (Table 2) revealed that both types of oils contain limonene $(29.87 \%-26.39 \%$ respectively) as major components. To the best of the researcher's knowledge, EOs from T. polium L. growing in Mascara (North West of Algeria) has been never reported in literature.

Monoterpene hydrocarbons, oxygenated monoterpenes and oxygenated sesquiterpene were the most represented in the flowering period (summer leaves), while the vegetative period (winter leaves) was characterized by a higher percentage of oxygenated monoterpenes, oxygenated sesquiterpene and low amount of monoterpene hydrocarbons.

The major compounds in regards to the vegetative period included limonene (29.87\%), spathulenol (17.24\%), camphor (8.20\%), pinocarvone $(7.76 \%)$, tau-cadinol (tow compounds: $5.41 \%$ and $7.88 \%)$, pinene oxide $(4.78 \%)$ and $\alpha$-terpineol (4.6\%). While, limonene (26.39\%), spathulenol (13.29\%), 1 -adamantanemethylamine $(9.80 \%)$, pinocarvone $(5.60 \%)$, $\beta$-myrcene (4.02\%), tau-cadinol (3.67\%) and $\alpha$-phellandrene $(3.45 \%)$ were the major compounds for the flowering period (Figure 2).

\section{Antioxidant Activity}

The results of the present study showed that the two tested EOs exhibited moderate antioxidant activity. However, the EO extracted from vegetative aerial parts (winter period) had the best activity with $\mathrm{IC}_{50}$ values from $3.90 \pm 0.05 \mathrm{mg}$ /
Table 2. Effect of Harvesting Times on Chemical Composition of Essential Oil of Teucrium polium

\begin{tabular}{lccc}
\hline Components & Retention time (min) & S1 & S2 \\
\hline$\alpha$-Phellandrene & 6.23 & - & 3.45 \\
\hline -Myrcene & 7.74 & - & 4.02 \\
\hline Pinene oxide & 7.74 & 4.78 & - \\
\hline Limonene & 9.81 & 29.87 & 26.39 \\
\hline Unknown 1 & 10.94 & - & 2.23 \\
\hline Unknown 2 & 11.46 & - & 2.14 \\
\hline Unknown 3 & 14.46 & 2.56 & - \\
\hline Unknown 4 & 15.45 & - & 2.86 \\
\hline Unknown 5 & 15.52 & 7.47 & - \\
\hline 1-Adamantanemethylamine & 15.53 & - & 9.85 \\
\hline Camphor & 15.87 & 8.20 & - \\
\hline Pinocarvone & 16.76 & 7.76 & 5.60 \\
\hline Unknown 6 & 18.54 & - & 2.09 \\
\hline$\alpha$-Terpineol & 18.72 & 4.60 & - \\
\hline Unknown 7 & 18.73 & - & 6.69 \\
\hline Spathulenol & 41.68 & 17.24 & 13.29 \\
\hline Tau-cadinol & 45.43 & 4.22 & - \\
\hline Tau-cadinol & 46.18 & 5.41 & 3.67 \\
\hline Unknown 8 & 61.62 & 7.88 & - \\
\hline Unknown 9 & 61.66 & - & 13.27 \\
\hline Unknown 10 & 61.73 & - & 2.46 \\
\hline Unknown 11 & 92.57 & - & 2.00 \\
\hline Total identified (\%) & & $87.45 \%$ & $100 \%$ \\
\hline & & & \\
\hline
\end{tabular}

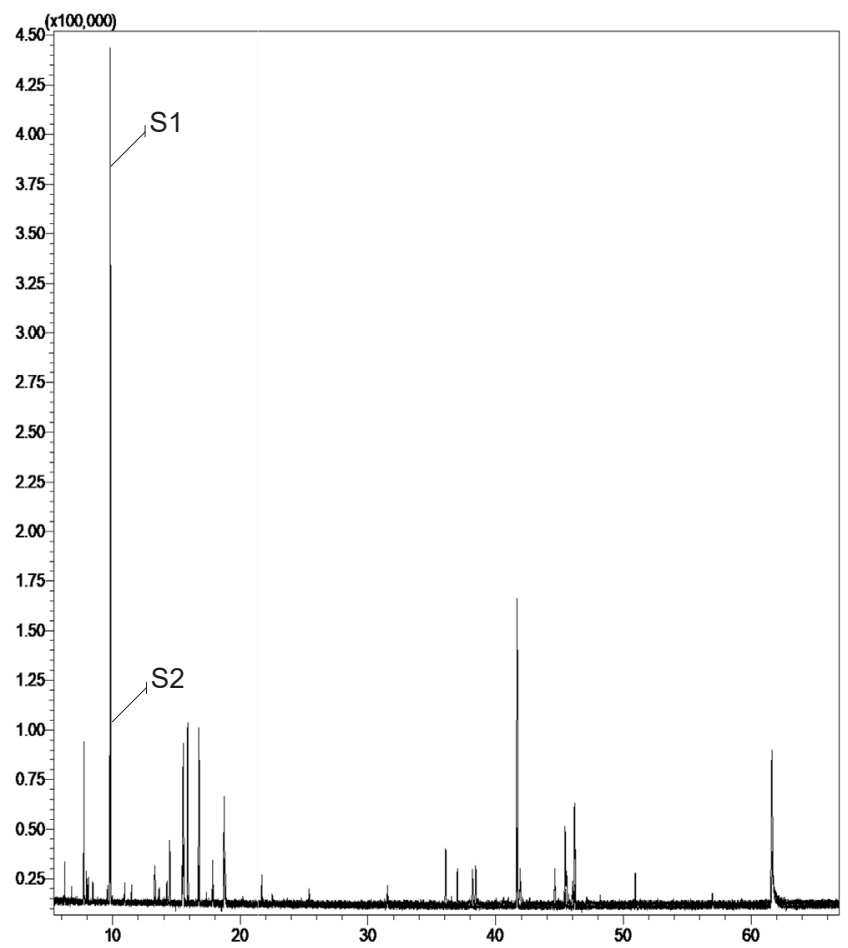

Figure 2. Comparison of Chemical Compounds Between Essential Oils at Vegetative Stage (S1) and Flowering Stage (S2) by GC-MS Analysis..

$\mathrm{mL}$ compared to the $\mathrm{EO}$ from the flowering stage $\mathrm{IC}_{50}=$ $16.14 \pm 0.15 \mathrm{mg} / \mathrm{mL}$, although they were less potent than the reference antioxidants (ascorbic acid) $\mathrm{IC}_{50}=0.0044 \pm 0.0002$ $\mathrm{mg} / \mathrm{mL}$ with $112.82,27.26 \mathrm{mg}$ ascorbic acid equivalents 
(AEAC) per g extracts scavenging $\mathrm{DPPH}^{\circ}$ radicals for EOs S1, S2, respectively $(P<0.001)$. Results are shown in Figure 3.

\section{Discussion}

The yield of EO of the aerial part of T. polium L. depends on the stages of the plant growth, where the vegetative stage (S1) was dominated significantly $(0.82 \%)$ following with the flowering (S2) stage $(0.56 \%)$. The EO yields obtained in the present study were comparable to what has been reported by Lianopoulou et $\mathrm{a}^{26}$ who found that winter leaves have a higher EO yield $(0.68 \%)$ compared to summer leaves $(0.37 \%)$ of T. polium collected in Northern Greece. They have also reported that winter leaves of $T$. polium exhibit a series of morphological and anatomical traits (absent in summer leaves) which may explain the higher production of EOs in winter as one of the defensive strategies against the chilling stress. Thus, McCaskill et $\mathrm{al}^{27}$ reported the high EO yield in the winter leaves which correspond to the higher number of peltate glandular hairs in winter leaves, since they are responsible for the biosynthesis of natural products such as EO, sucrose esters and phenolic compounds. However, winter chilling stress activates oxidative stress in cells, ${ }^{28}$ and induces the production of antioxidant enzymes and non-enzymatic antioxidants such as phenolic compounds, etc. ${ }^{29}$

The winter leaves of T. polium have a higher photosynthetic rate compared to summer leaves. Furthermore, their mesophyll cells are dense and their chloroplasts are larger and more numerous with a higher number of grana which reflect to a larger $\mathrm{CO}_{2}$ absorption area, and induce an increase in the rate of photosynthesis. In this fact, cells produce larger amounts of photosynthetic carbon which are invested in the biosynthesis of secondary metabolites necessary for the protection against the stress of low temperature such as phenolic compounds, EO etc. ${ }^{26}$ The decrease of the yield of EO in the phenological stages (vegetative to flowering stages) was explicated by the adaptation of $T$. polium to climatic variation. Thus, the metabolites of the terpenoid pathway (monoterpenes, sesquiterpenes, and homoterpenes) were involved in many plant physiology and ecology. ${ }^{30}$

According to the physico-chemical properties, good quality EOs have higher density, higher ester value and lower value of refractive index. The acid value must be less than 2 (low amount of free acids). ${ }^{31}$

Hassan et $\mathrm{al}^{32}$ found that oil extracted from T. polium growing in Saudi Arabia is light yellow, fragrant and pungent characteristic odor with refractive value 1.4850 .

The EOs of T. polium exhibit a very important chemical polymorphism. Several studies have shown a variation in the chemical compositions of oils (several chemotypes) according to geographical origin, plant organ and vegetative cycle stage:

From the Western region of Algeria (Tlemcen province), the main compounds of the EOs of T. polium (subsp. polium) were germacrene D (25.81\%), bicyclogermacrene (13\%), ß-pinene (11.69\%) and carvacrol (8.93\%). ${ }^{33}$ However, Djabou et $\mathrm{al}^{34}$ found that $\beta$-pinene (16.6\%), germacrene $\mathrm{D}(14.8 \%)$, a-pinene (7.2\%), spathulenol (6.4\%), limonene (5.6\%), bicyclogermacrene $(5.5 \%)$ and myrcene $(2.9 \%)$ were the major components. In Eastern Algeria, EOs from Setif have a

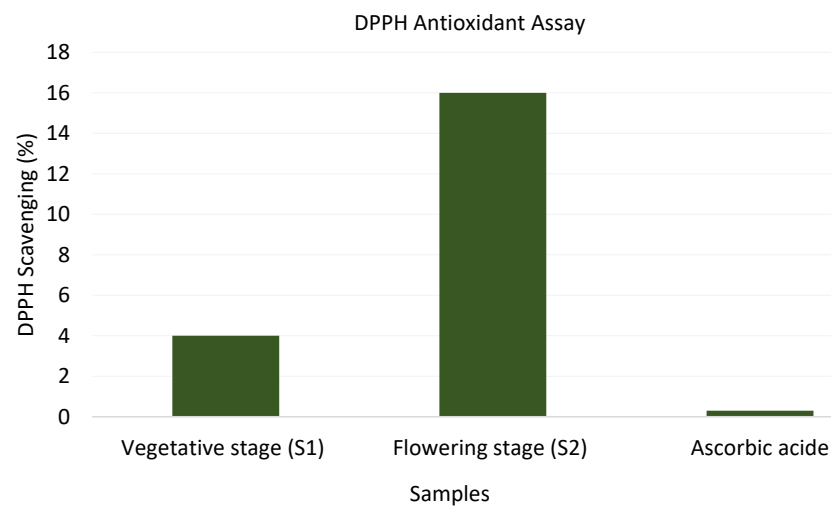

Figure 3. Antioxidant Activity of Essential Oils of Teucrium polium Using DPPH Antioxidant Assay. IC50 values showed significant differences between the samples and ascorbic acid at $P<0.001$.

chemotype characterized by a-pinene (14.1-18.0\%), $\beta$-pinene (15.3-18.1\%), germacrene-D (3.8-19\%), myrcene (8.2-10.4\%), limonene $(5.3-8.7 \%)^{35}$ and from Ain Melilla-Aures, the chemotype: $\alpha$-cadinol (46.8\%), 3- $\beta$-hydroxy- $\alpha$-muurolene (22.5\%), $\alpha$-pinene $(9.5 \%)$ and $\beta$-pinene $(8.3 \%)$ have been identified. ${ }^{36}$ In South Algeria, EOs from Tamanrasset (central Hoggar) contained dl-Limonene $(11.18 \%), \quad \delta$-cadinene $(10.02 \%)$ and trans $\beta$-caryophyllene $(9.15 \%)$ as the main components. ${ }^{37}$

Essential oils of the aerial parts of T. polium (collected during the flowering stage in June) growing in Tunisia contained $\alpha$-pinene (17.04\%), $\beta$-pinene (12.68\%), and limonene (6.65\%), $\beta$-myrcene (6.07\%) and germacrene $\mathrm{D}(5.89 \%){ }^{38}$

The EOs extracted from the T. polium growing in Aydin/ Turkey contained $(8.10 \%)$ germacrene $\mathrm{D},(5.41 \%)$ carvacrol, (4.63\%) $\beta$-pinene, (3.40\%) $\alpha$-copaene, (3.32\%) spathulenol as the major constitutes. ${ }^{39}$

Teucrium polium from Iran characterized by the presence of $\alpha$-pinene (18.2\%), elemol (14.5\%), $\beta$-pinene (10.1\%), cubenol $(10.0 \%)$, and limonene $(5.0 \%)$ are the major constituents of fruit oil. ${ }^{40}$

Cozzani et $\mathrm{al}^{41}$ mentioned that $\alpha$-pinene (28.8\%), $\beta$-pinene (7.2\%) and p-cymene (7.0\%) were major components of EO of the aerial parts of T. polium subsp. capitatum, collected in October from Corsica, France.

In general, it appears that the qualitative and quantitative changes of the EO composition of T. polium are significantly related with its development (the presence/absence of some typical components and the amount of the main constituents). Therefore, the variability of the chemical composition of EOs affects their antioxidant activity. As a result, the EOs extracted from the vegetative aerial parts had the best activity $\left(\mathrm{IC}_{50}=3.90 \pm 0.05 \mathrm{mg} / \mathrm{mL}\right)(P<0.001)$. This is while, Mahmoudi and Nosratpour ${ }^{42}$ found that the EO of T. polium L. (collected during flowering stage) from the West of Iran (Kerman province) was able to reduce the stable free radical DPPH with an $\mathrm{IC}_{50}=9200 \mu \mathrm{g} / \mathrm{mL}$, where the main constituents were Spathulenol (15.06\%), $\beta$-pinene (11.02\%), $\beta$-myrcene $(10.05 \%)$, germacrene $\mathrm{B}(10.11 \%)$, germacrene D (8.15\%), bicyclogermacrene (8.25\%) and linalool (4.02\%). 
Hammoudi et $\mathrm{al}^{37}$ found that the main compounds in the EO of T. polium (collected in November) were dl-limonene $(11.18 \%), \delta$-cadinene $(10.02 \%)$ and trans $\beta$-caryophyllene $(9.15 \%)$ with a potential activity from $79.02 \pm 0.00 \mathrm{mg}$ AEAC per $g$ extracts scavenging $\mathrm{DPPH}^{\cdot}$ radicals. However, $T$. polium subsp. capitatum oil ( collected in July) with t-cadinol (18.3\%), germacrene D (15.3\%) and $\beta$-pinene (10.5\%) as the major components represented less efficiency than that of positive control (BHA) reaching a maximum of $12.7 \%$ for a concentration of $1000 \mathrm{mg} / \mathrm{L} .^{43}$

Lemos et $\mathrm{al}^{44}$ also showed that the EOs of Thymus vulgaris $L$ (Lamiaceae family, 125 samples from Brazil harvested in each season) had moderate antioxidant activities evaluated by the DPPH method, and justified by the presence of the monoterpenes.

Thus, in the present study, the antioxidant activities of $T$. polium EOs can be attributed to the high concentration of major components, the variation in chemical composition, the presence/absence the oxygenated monoterpenes, monoterpene hydrocarbons and sesquiterpene. Furthermore, defining the component (s) responsible for this activity is very difficult.

Generally, EOs contain phenolic and non-phenolic compounds while phenolic compounds such as carvacrol and thymol have strong antioxidant potentials. ${ }^{45,46}$ Whereas, the phenolic compound is a source of $n \mathrm{H}$ atoms that are transferred to $\mathrm{DPPH}^{\cdot}$ free radical then $\mathrm{DPPH}^{\cdot}$ converted into a stable molecule DPPH. Therefore, the addition of an antioxidant results on a decrease of absorbance proportional to the concentration and antioxidant activity of the compound. ${ }^{47}$ However, some researchers have revealed that some EOs rich in non-phenolic compounds also had antioxidant potentials. ${ }^{48-50}$ Wei and Shibamoto ${ }^{51}$ revealed that EOs contain high percentages of hydrocarbon monoterpenes such as limonene and $\alpha$-pinene, which demonstrate a significant antioxidant potential. Miguel ${ }^{52}$ reported a good antioxidant activity for the EOs of Citrus sinensis, where limonene was the major constituents. According to Bayala et al, ${ }^{53}$ the major constituents were $\alpha$-terpineol (59.78\%) and $\beta$-caryophyllene (10.54\%) for Ocimum basilicum (Lamiaceae family) with the best ability to scavenge DPPH radical created in vitro with a percentage of inhibition of $55.67 \%$ for a concentration of 8 $\mathrm{mg} / \mathrm{mL}$.

Zengin and Baysal ${ }^{54}$ tested some compounds individually and they showed that the overall antioxidant activity of a-terpineol was stronger than linalool and eucalyptol. Although Bicas et $\mathrm{al}^{55}$ evaluated the antioxidant and antiproliferative activities of a-terpineol, they reported that this component exhibited potent free radical-scavenging activity and also had a cytostatic effect against six human cancerous cell lines (breast, lung, prostate, ovarian, and leukemia).

Antioxidant activity of the oil extracted from the leaves of Ocimum canum Sims. (Lamiaceae family) showed dose dependent free radical scavenging activity against $\mathrm{DPPH}$ $\left(\mathrm{IC}_{50} 523.55 \pm 0.001 \mu \mathrm{g} / \mathrm{mL}\right.$ ), where the major compound was camphor $(39.77 \%) .{ }^{56} \mathrm{De}$ Lima et $\mathrm{al}^{57}$ found that 45 components with a predominance of monoterpenes, such as camphor
(51.81\%), 1,8-cineole (20.13\%) and limonene (11.23\%) in the EO of Ocimum kilimandscharicum (Lamiaceae family) which has demonstrated antioxidant capacity against DPPH with an $\mathrm{IC}_{50}$ of $8.31 \mu \mathrm{g} / \mathrm{mL}$ compared to pure camphor $\left(\mathrm{IC}_{50}=12.56\right.$ $\mu \mathrm{g} / \mathrm{mL})$ and mixture of the limonene: 1,8 -cineole $\left(\mathrm{IC}_{50}=23.25\right.$ $\mu \mathrm{g} / \mathrm{mL}$ ) displayed a potent activity.

It has been reported that the overall antioxidant activity of oxygenated monoterpenes (linalool, carvacrol, a-terpineol

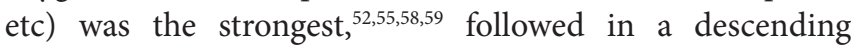
order by monoterpene hydrocarbons and sesquiterpene hydrocarbons and their oxygenated derivatives which have very low antioxidant activities. ${ }^{60}$

According to Viuda-Martos et al, ${ }^{61}$ the good antioxidant activity of EOs compared to individual components can be attributed to the synergistic interaction of the EO constituents, the high percentages of the main components or to the micro components acting as pro-oxidants.

Although, some researchers have revealed that most natural antioxidative compounds (such as EO constituents, phenolic compounds, etc) often work synergistically with each other to create an effective defense system against free radical attack..$^{62,63}$

\section{Conclusions}

Teucrium polium L. is a seasonally dimorphic plant showing its ability to adaptation to the drought stress and the chilling stress (the climatic variation). However, this variation effects the chemical composition of EOs (vegetative stage/flowering stage) and therefore their antioxidant activity. This fact is actually of great interest because the ability of T. polium EOs collected from the Mascara province may play an important role in the prevention of some diseases such as cancer and inflammatory diseases.

According to the results of the present study, the vegetative stage is selected as the best stage for harvesting the EO of Teucrium polium L. with the best antioxidant activity compared to the flowering stage EO.

\section{Authors' Contributions}

YM, BM and ATTM designed the study. JAGH performed the experiments (GC-MS analysis). YM prepared the samples, carried out the experiments and wrote the manuscript with input from all authors.

\section{Conflict of Interest Disclosures}

The authors declare they have no conflicts of interest.

\section{Acknowledgments}

The authors would like to thank the University Mustapha Stambouli of Mascara and the Algeria Ministry of Higher Education and Scientific Research for their guidance during this research.

\section{References}

1. Pham-Huy LA, He H, Pham-Huy C. Free radicals, antioxidants in disease and health. Int J Biomed Sci. 2008;4(2):89-96.

2. Lagouri V, Boskou D. Screening for antioxidant activity of essential oils obtained from spices. In: Charalambous G, ed. Developments in Food Science. Vol 37: Elsevier; 1995. p. 869-879. doi:10.1016/ S0167-4501(06)80203-7.

3. Chemsa AE, Zellagui A, Öztürk M, et al. Chemical composition, antioxidant, anticholinesterase, antimicrobial and antibiofilm activities of essential oil and methanolic extract of Anthemis 
stiparum subsp. sabulicola (Pomel) Oberpr. Microb Pathog. 2018;119:233-240. doi:10.1016/j.micpath.2018.04.033.

4. De Marino S, Festa C, Zollo F, et al. Antioxidant activity of phenolic and phenylethanoid glycosides from Teucrium polium L. Food Chem. 2012;133(1):21-28. doi:10.1016/j.foodchem.2011.12.054.

5. Cunningham CJ, Weathington BL, Pittenger DJ. Understanding and Conducting Research in the Health Sciences. John Wiley \& Sons; 2013. p. 544.

6. Quezel P, Santa S. Nouvelle Flore de I'Algérie et des Régions Désertiques Méridionales. Paris: CNRS; 1962. p. 1170.

7. Gharaibeh MN, Elayan HH, Salhab AS. Hypoglycemic effects of Teucrium polium. J Ethnopharmacol. 1988;24(1):93-99. doi:10.1016/0378-8741(88)90139-0.

8. Tariq M, Ageel AM, Al-Yahya MA, Mossa JS, Al-Said MS. Antiinflammatory activity of Teucrium polium. Int J Tissue React. 1989;11(4):185-188.

9. Rasekh HR, Khoshnood-Mansourkhani MJ, Kamalinejad M. Hypolipidemic effects of Teucrium polium in rats. Fitoterapia. 2001;72(8):937-939. doi:10.1016/S0367-326X(01)00348-3.

10. Couladis M, Tzakou O, Verykokidou E, Harvala C. Screening of some Greek aromatic plants for antioxidant activity. Phytother Res. 2003;17(2):194-195. doi:10.1002/ptr.1261.

11. Sayyad R, Farahmandfar R. Influence of Teucrium polium L. essential oil on the oxidative stability of canola oil during storage. J Food Sci Technol. 2017;54(10):3073-3081. doi:10.1007/s13197017-2743-0.

12. Allahtavakoli M, Moradi R, Shamsi S, Afsharmanesh K. Effect of hydro-alcoholic extract of Teucrium polium on castor oil-induced diarrhea in male rat. Zahedan J Res Med Sci. 2013;15(6):54-57.

13. Mahmoudabady M, Haghshenas M, Niazmand S. Extract from Teucrium polium L. protects rat heart against oxidative stress induced by ischemic-reperfusion injury. Adv Biomed Res. 2018;7:15. doi:10.4103/abr.abr_218_16.

14. Šamec D, Durgo K, Grúz J, et al. Genetic and phytochemical variability of six Teucrium arduini L. populations and their antioxidant/prooxidant behaviour examined by biochemical, macromolecule- and cell-based approaches. Food Chem. 2015;186:298-305. doi:10.1016/j.foodchem.2014.07.135.

15. Daghbouche S, Daghbouche AE, Boulessnam B, Snoussi SA, Djazouli ZE. Influence of phenological stages on chemical composition and antimicrobial activities of Teucrium polium essential oils from North East of Algeria. J Fundam Appl Sci. 2018;10(5S):32-65. doi:10.4314/jfas.v10i5s.3.

16. Boussoussa H, Khacheba I, Djeridane A, Mellah N, Yousfi M. Antibacterial activity from Rhanterium adpressum flowers extracts, depending on seasonal variations. Ind Crops Prod. 2016;83:44-47. doi:10.1016/j.indcrop.2015.12.020.

17. Verma RS, Verma RK, Chauhan A, Yadav AK. Seasonal variation in essential oil content and composition of Thyme, Thymus serpyllum L. cultivated in Uttarakhand Hills. Indian J Pharm Sci. 2011;73(2):233-235. doi:10.4103/0250-474x.91570.

18. Ghasemi Pirbalouti A, Firoznezhad M, Craker L, Akbarzadeh M. Essential oil compositions, antibacterial and antioxidant activities of various populations of Artemisia chamaemelifolia at two phenological stages. Rev Bras Farmacogn. 2013;23(6):861-869. doi:10.1590/S0102-695X2013000600002.

19. Zaouali Y, Chograni H, Trimech R, Boussaid M. Changes in essential oil composition and phenolic fraction in Rosmarinus officinalis L. var. typicus Batt. organs during growth and incidence on the antioxidant activity. Ind Crops Prod. 2013;43(1):412-419. doi:10.1016/j.indcrop.2012.07.044.

20. Council of Europe. European Pharmacopoeia. 5th ed. Strasbourg: Council of Europe; 2004. p. 217-218.

21. AFNOR. Essential oils. Ed. PARA Graphic. Part 1 - Sampling and method of analysis 471 p. Part 2 - Volume 1 Monograph relating to essential oils. Part 2 - Volume 2 Monograph relating to essential oils. 2000; p. 663.

22. Brand-Williams W, Cuvelier ME, Berset C. Use of a free radical method to evaluate antioxidant activity. LWT - Food Sci Technol. 1995;28(1):25-30. doi:10.1016/S0023-6438(95)80008-5.

23. Ndoye Foe FM, Tchinang TFK, Nyegue AM, et al. Chemical composition, in vitro antioxidant and anti-inflammatory properties of essential oils of four dietary and medicinal plants from Cameroon. BMC Complement Altern Med. 2016;16:117. doi:10.1186/s12906-016-1096-y.

24. Leong LP, Shui G. An investigation of antioxidant capacity of fruits in Singapore markets. Food Chem. 2002;76(1):69-75. doi:10.1016/ S0308-8146(01)00251-5.

25. Lim YY, Lim TT, Tee JJ. Antioxidant properties of several tropical fruits: a comparative study. Food Chem. 2007;103(3):1003-1008. doi:10.1016/j.foodchem.2006.08.038.

26. Lianopoulou V, Bosabalidis AM, Patakas A, Lazari D, Panteris E. Effects of chilling stress on leaf morphology, anatomy, ultrastructure, gas exchange, and essential oils in the seasonally dimorphic plant Teucrium polium (Lamiaceae). Acta Physiol Plant. 2014;36(8):2271-2281. doi:10.1007/s11738-014-1605-x.

27. McCaskill D, Gershenzon J, Croteau R. Morphology and monoterpene biosynthetic capabilities of secretory cell clusters isolated from glandular trichomes of peppermint (Mentha piperita L.). Planta. 1992;187(4):445-454. doi:10.1007/bf00199962.

28. Imahori Y, Takemura M, Bai J. Chilling-induced oxidative stress and antioxidant responses in mume (Prunus mume) fruit during low temperature storage. Postharvest Biol Technol. 2008;49(1):5460. doi:10.1016/j.postharvbio.2007.10.017.

29. Bafeel SO, Ibrahim MM. Antioxidants and accumulation of $\alpha$-tocopherol induce chilling tolerance in Medicago sativa. Int J Agric Biol. 2008;10(6):593-598.

30. Dudareva N, Negre F, Nagegowda DA, Orlova I. Plant volatiles: recent advances and future perspectives. Crit Rev Plant Sci. 2006;25(5):417-440. doi:10.1080/07352680600899973.

31. AFNOR. French standard NF ISO 3063: essential oil of ylangylang [Cananga odorata (Lamarck) J.D. Hooker \& Thomson forma genuina]. Paris: AFNOR; 2005.

32. Hassan MM, Muhtadi FJ, Al-Badr AA. GLC-mass spectrometry of Teucrium polium oil. J Pharm Sci. 1979;68(6):800-801. doi:10.1002/jps.2600680639.

33. Belmekki N, Bendimerad N, Bekhechi C, Fernandez X. Chemical analysis and antimicrobial activity of Teucrium polium L. essential oil from Western Algeria. J Med Plant Res. 2013;7(14):897-902.

34. Djabou N, Muselli A, Allali $\mathrm{H}$, et al. Chemical and genetic diversity of two Mediterranean subspecies of Teucrium polium L. Phytochemistry. 2012;83:51-62. doi:10.1016/j. phytochem.2012.05.019.

35. Lograda T, Ramdani M, Chalard P, Figueredo G, Deghar A. Chemical analysis and antimicrobial activity of Teucrium polium L. essential oil from eastern Algeria. Am J Adv Drug Deliv. 2014;2(6):697-710.

36. Kabouche A, Kabouche Z, Ghannadi A, Sajjadi SE. Analysis of the essential oil of Teucrium polium ssp. aurasiacum from Algeria. J Essent Oil Res. 2007;19(1):44-46. doi:10.1080/10412905.2007.9 699227.

37. Hammoudi R, Hadj-Mahammed M, Ould El-Hadj MD. Chemical composition and antioxidant and antimicrobial activities of the essential oil from Teucrium polium geyrii (Labiatae). J Med Plant Res. 2013;7(20):1506-1510. doi:10.5897/jmpr13.5082.

38. Bakari S, Ncir M, Felhi S, et al. Chemical composition and in vitro evaluation of total phenolic, flavonoid, and antioxidant properties of essential oil and solvent extract from the aerial parts of Teucrium polium grown in Tunisia. Food Sci Biotechnol. 2015;24(6):19431949. doi:10.1007/s10068-015-0256-z.

39. Kurtoğlu C, Tin B. Essential oil composition of Teucrium polium L. Grown in Aydın/Turkey. Turk J Life Sci. 2017;2(1):142-144.

40. Sabzeghabaie A, Asgarpanah J. Essential oil composition of Teucrium polium L. fruits. J Essent Oil Res. 2016;28(1):77-80. doi: 10.1080/10412905.2015.1082947.

41. Cozzani S, Muselli A, Desjobert JM, Bernardini AF, Tomi F, 
Casanova J. Chemical composition of essential oil of Teucrium polium subsp. capitatum (L.) from Corsica. Flavour Fragr J. 2005;20(4):436-441.

$$
\text { doi:10.1002/ffj.1463. }
$$

42. Mahmoudi R, Nosratpour S. Teucrium polium L. essential oil: phytochemiacl component and antioxidant properties. Int Food Res J. 2013;20(4):1697-1701.

43. Kerbouche L, Hazzit M, Ferhat M-A, Baaliouamer A, Miguel MG. Biological Activities of Essential Oils and Ethanol Extracts of Teucrium polium subsp. capitatum (L.) Briq. and Origanum floribundum Munby. J Essent Oil Bear Plants. 2015;18(5):11971208. doi:10.1080/0972060X.2014.935065.

44. Lemos MF, Lemos MF, Pacheco HP, et al. Seasonal variation affects the composition and antibacterial and antioxidant activities of Thymus vulgaris. Ind Crops Prod. 2017;95:543-548. doi:10.1016/j. indcrop.2016.11.008.

45. Alma MH, Mavi A, Yildirim A, Digrak M, Hirata T. Screening chemical composition and in vitro antioxidant and antimicrobial activities of the essential oils from Origanum syriacum L. growing in Turkey. Biol Pharm Bull. 2003;26(12):1725-1729. doi:10.1248/ bpb.26.1725.

46. Aidi Wannes W, Mhamdi B, Sriti J, et al. Antioxidant activities of the essential oils and methanol extracts from myrtle (Myrtus communis var. italica L.) leaf, stem and flower. Food Chem Toxicol. 2010;48(5):1362-1370. doi:10.1016/j.fct.2010.03.002.

47. Villaño D, Fernández-Pachón MS, Moyá ML, Troncoso AM, García-Parrilla MC. Radical scavenging ability of polyphenolic compounds towards DPPH free radical. Talanta. 2007;71(1):230235. doi:10.1016/j.talanta.2006.03.050.

48. El-Massry KF, El-Ghorab AH, Farouk A. Antioxidant activity and volatile components of Egyptian Artemisia judaica L. Food Chem. 2002;79(3):331-336. doi:10.1016/S0308-8146(02)00164-4.

49. Juteau F, Masotti V, Bessiere JM, Dherbomez M, Viano J. Antibacterial and antioxidant activities of Artemisia annua essential oil. Fitoterapia. 2002;73(6):532-535. doi:10.1016/s0367326x(02)00175-2.

50. Yildirim A, Cakir A, Mavi A, Yalcin M, Fauler G, Taskesenligil Y. The variation of antioxidant activities and chemical composition of essential oils of Teucrium orientale L. var. orientale during harvesting stages. Flavour Fragr J. 2004;19(5):367-372. doi:10.1002/ffj.1343.

51. Wei A, Shibamoto T. Antioxidant activities and volatile constituents of various essential oils. J Agric Food Chem. 2007;55(5):17371742. doi:10.1021/jf062959x.

52. Miguel MG. Antioxidant and anti-inflammatory activities of essential oils: a short review. Molecules. 2010;15(12):9252-9287. doi:10.3390/molecules15129252.

53. Bayala B, Bassole IH, Gnoula C, et al. Chemical composition, antioxidant, anti-inflammatory and anti-proliferative activities of essential oils of plants from Burkina Faso. PLoS One. 2014;9(3):e92122. doi:10.1371/journal.pone.0092122.

54. Zengin H, Baysal AH. Antibacterial and antioxidant activity of essential oil terpenes against pathogenic and spoilage-forming bacteria and cell structure-activity relationships evaluated by SEM microscopy. Molecules. 2014;19(11):17773-17798. doi:10.3390/ molecules191117773.

55. Bicas JL, Neri-Numa IA, Ruiz AL, De Carvalho JE, Pastore GM. Evaluation of the antioxidant and antiproliferative potential of bioflavors. Food Chem Toxicol. 2011;49(7):1610-1615. doi:10.1016/j.fct.2011.04.012.

56. Tamil Selvi M, Thirugnanasampandan R, Sundarammal S. Antioxidant and cytotoxic activities of essential oil of Ocimum canum Sims. from India. J Saudi Chem Soc. 2015;19(1):97-100. doi:10.1016/j.jscs.2011.12.026.

57. de Lima VT, Vieira MC, Kassuya CA, et al. Chemical composition and free radical-scavenging, anticancer and anti-inflammatory activities of the essential oil from Ocimum kilimandscharicum. Phytomedicine. 2014;21(11):1298-1302. doi:10.1016/j. phymed.2014.07.004.

58. Maestri DM, Nepote V, Lamarque AL, Zygadlo JA. Natural products as antioxidants. In: Imperato F, ed. Phytochemistry: Advances in Research; 2006. p. 105-135.

59. Barbieri N, Costamagna M, Gilabert M, et al. Antioxidant activity and chemical composition of essential oils of three aromatic plants from La Rioja province. Pharm Biol. 2016;54(1):168-173. doi:10.3 109/13880209.2015.1028077.

60. Ruberto G, Baratta MT. Antioxidant activity of selected essential oil components in two lipid model systems. Food Chem. 2000;69(2):167-174. doi:10.1016/S0308-8146(99)00247-2.

61. Viuda-Martos M, López-Marcos MC, Fernández-López J, Sendra E, López-Vargas JH, Pérez-Álvarez JA. Role of fiber in cardiovascular diseases: a review. Compr Rev Food Sci Food Saf. 2010;9(2):240258. doi:10.1111/j.1541-4337.2009.00102.x.

62. LuY, Foo LY. Antioxidant activities of polyphenols from sage (Salvia officinalis). Food Chem. 2001;75(2):197-202. doi:10.1016/S03088146(01)00198-4.

63. Singh G, Marimuthu P, de Heluani CS, Catalan CA. Antioxidant and biocidal activities of Carum nigrum (seed) essential oil, oleoresin, and their selected components. J Agric Food Chem. 2006;54(1):174-181. doi:10.1021/jf0518610. 